\title{
FIÁTH TITANILLA
}

\section{Szörnyetegek habilitáción}

\author{
Egy amerikai, szexuálisbün-elkövetőknek kidolgozott \\ börtönprogramon végzett terepmunka tapasztalatai
}

\begin{abstract}
„Korábban undorodtam az ilyen emberektöl - közli a csoportfoglalkozáson egy tizenéves lánnyal létesített szexuális kapcsolat miatt elítélt férfi. - Letöltöttem a mobilomra egy sex offender [szexuálisbün-elkövetö] alkalmazást, és folyamatosan figyeltem, nem költözik-e valamelyikük a környékünkre.” ,Igen, én is mindig néztem öket a neten, mert két kisgyerekem van - teszi hozzá egy másik résztvevö. - Sosem gondoltam volna, hogy egyszer nekem is regisztrálnom kell majd."

Noha az Egyesült Államokban a letartóztatottak csupán egy százalékát vádolják meg valamilyen szexuális jellegü büncselekménnyel ${ }^{1}$, illetve annak ellenére, hogy a cselekmények jelentős hányadát családtagok és egyéb, az áldozathoz közel álló személyek követik el ${ }^{2}$, a közbeszédben a szexuálisbün-elkövetőkre használt leggyakoribb metaforák a ragadozó, illetve a szörnyeteg képét idézik fel. Douard és Schultz szerint ${ }^{3}$ az ártatlanok körül settenkedö, erkölcsileg romlott, démonikus erőkkel felruházott rém alakja elsősorban arra szolgál, hogy a szexuálisbün-elkövetőket megfosszuk emberi értékeiktől, és dehumanizáljuk (így a későbbiekben igazolhatjuk a vele szemben alkalmazott, sok esetben embertelen eljárásokat is).

2014 áprilisától négy hónapon keresztül végeztem résztvevő megfigyelést egy szexuálisbün-elkövetőknek kidolgozott amerikai börtönprogram dolgozói és kliensei körében. ${ }^{4}$ James $B$. Waldrammal - egy kanadai szexuálisbünelkövetők részlegén terepmunkát végző antropológussal - ellentétben, aki ki-
\end{abstract}

\footnotetext{
1 Center for Sex Offender Management: The Role of the Victim and Victim Advocate in Managing Sex Offenders. Corrections.com, July 27 2009. http://www.corrections.com/news/article/21987

2 Roger N. Lancaster: Sex Offenders: The Last Pariahs. The New York Times, 21 August 2011; Susan A. Clancy: The Trauma Myth. The Truth about the Sexual Abuse of Children - and Its Aftermath. Basic Books, New York, 2009

3 John Douard - Pamela D. Schultz: Monstrous Crimes and the Failure of Forensic Psychiatry. Springer, New York, 2012

$4 \mathrm{Az}$ adott államot a továbbiakban sem nevezem meg, mivel pontosítás esetén a szóban forgó terápiás körletek, azok lakói és dolgozói könnyen azonosíthatóvá válnának. Hasonló okok miatt a tanulmányban szereplök nevét is megváltoztattam.
} 
zárólag fogvatartottakkal készített interjúkat, én főként az elítéltek csoportfoglalkozásain vettem részt, illetve a terapeutáikkal beszélgettem. Kutatói stratégiám elsősorban a szörnyeteg-metaforával, a szexuálisbün-elkövetők démonizálásával szorosan összefüggő, szigorú intézeti szabályozáshoz semmint a saját szándékaimhoz - illeszkedett, amelynek értelmében még a börtön dolgozói sem tarthatnak egyéni konzultációt a klienseiknek. Ha a terapeuták valamelyik fogvatartottal a csoportos kereteken kívül szeretnének beszélni, azt vagy az egyik nagyteremben, a többiektől kissé elkülönülve - de mindvégig az elítéltcsoporttal egy térben tartózkodva - tehetik meg, vagy kötelesek az irodájukba hívni egy fogvatartott-társat is ellenőrzés céljából. Mindezek miatt az elítéltekkel történő személyesebb hangvételü beszélgetésekre csak olyankor nyílt lehetőségem, amikor kiscsoportban dolgoztak, és a terapeutától függetlenül is leülhettem közéjük meghallgatni, hogyan oldanak meg egy-egy feladatot.

Az általam meglátogatott terápiás program 1990-ben indult, az állami büntetés-végrehajtási szervezet közleménye szerint azzal a szándékkal, hogy kezelést nyújtsanak a már bírósági ítélettel rendelkező szexuálisbün-elkövetőknek annak érdekében, hogy a szabadulásuk után tartózkodjanak újabb büncselekmények elkövetésétől (vagyis hogy alacsonyabbak legyenek a visszaesési mutatók és erősödjön a közbiztonság). Az intézeti hírlevélben olvasható rövid célkitüzés egyúttal számos olyan feltételezésre is rávilágít, amelyek a program alapvetéseit alkotják:

- Annak ellenére, hogy a szemérem elleni erőszaktól a tizenévesekkel való szexuális együttléten át a gyermekpornográfia birtoklásáig igen sokféle bủncselekmény tartozik a sex crimes jogi kategóriájába, illetve amellett, hogy a szexuálisbün-elkövetők rendkívül heterogén csoportot alkotnak ${ }^{5}$, a program célravezetőnek és értelmesnek találja, hogy pszichológiai vagy egyéb jellemzök helyett a büncselekmény jellege szolgáljon az elkövetők csoportos kezelésbe vételének alapjául.

- A kizárólag szexuálisbün-elkövetők számára bevezetett kezelés egyúttal arra is rámutat, hogy a bünelkövetö-populációban kiemelt figyelemmel kísérendők. Noha más bűncselekmények esetében a gyakorisági mutatók és a visszaeséssel kapcsolatos adatok jóval magasabbak, mégis a szexuálisbünelkövetők csoportja az egyetlen, amelytöl szigorú szankciókkal kell védeni a lakosságot (az elöírt terápiás program mellett ezt a célt szolgálja a szabadulásukat követő regisztráció, a pártfogó felügyelő kirendelése, illetve a

5 John Douard - Pamela D. Schultz: i. m. 10. o. 
közösségi szexuálisbün-elkövetőknek szervezett terápiás programok látogatásnak kötelezettsége is).

- A program létrehozása egyúttal feltételezi azt is, hogy a szexuális bünök elkövetőinek jól körülhatárolható pszichés zavaraik vannak, amelyeket valamilyen, elsősorban lélektani alapokon nyugvó kezelésnek kell célba vennie és korrigálnia. Ezzel szemben a vonatkozó kutatások szerint a szexuálisbün-elkövetök nem mutatnak több pszichoszexuális rendellenességet, mint a szexuális bünökért el nem ítélt populáció ${ }^{6}$.

- A terápiás cél egyértelmủen a bünismétlés megelőzése. Ha a program résztvevője civilben drogokhoz nyúl, esetleg pszichiátriai vagy egyéb nehézségei támadnak (depresszió, öngyilkosság, munkanélküliség stb.), ámde szexuális jellegü büncselekmény miatt nem kap újabb ítéletet, az a program sikereként könyvelhetö majd el.

Az elítélt szexuálisbün-elkövetők a börtönbüntetésük utolsó kilenc-tizenkét hónapját töltik el a program végrehajtására kijelölt intézetben (az alapprogram kilenc hónapig tart, amely a fogvatartott „nehézségeinek” és „terápiás igényeinek" függvényében a kezelésért felelős személyzet döntése alapján maximum egyévnyi időtartamra meghosszabbítható). A kb. 2600 főt fogva tartó börtön egyik elkülönített, 240 elítélt befogadására alkalmas, 20-as számú épülete ad otthont a Sex Offender programnak; az A, B, C és D szárnyakon hatvan-hatvan fogvatartott tölti a büntetését. A jogszabályok értelmében a résztvevők kedvezményes szabadon bocsátásának feltétele a program sikeres elvégzése. Azok, akik akár magánelzárás-büntetéssel sújtható, súlyosabb fegyelmi vétség, akár a programmal való együttmüködés képtelensége miatt nem fejezik be a kezelést, nem kapják meg a feltételes szabadlábra bocsátás lehetőségét (ami esetenként többéves bv. intézetben tartózkodást jelent számukra a korai szabadulás helyett).

A program első, rövidebb - négyhetes - szakaszában az újonnan érkezetteket különböző pszichológiai tesztekkel és interjúkkal vizsgálják meg. A fogvatartott első interjú- és tesztvizsgálatának jellemzői ugyancsak rámutatnak a program fontosabb alapvetéseire:

- Az elítélt személyiségének komplexitása, egyedi jellemzői kevésbé fontosak, mint azok a büncselekményével összefüggésbe hozott tulajdonságok, amelyek feltételezhetően a jövőbeli viselkedését is meghatározzák majd. A mérés fó-

6 James B. Waldram: Hound Pound Narrative: Sexual Offender Habilitation and the Anthropology of Therapeutic Intervention. University of California Press, Berkeley, 2012, p. 56. 
kuszpontjai egyértelmüen jelzik a kliensnek, hogy a következő hónapokban kizárólag sex offenderként kerül a terápiás beavatkozás hatálya alá.

- A büncselekménnyel kapcsolatba nem hozható jellemzők figyelmen kívül hagyása megerősíti a kezelés fő célkitüzését: a hagyományos pszichoterápiákkal ellentétben a treatment itt elsősorban mások javát szolgálja ${ }^{7}$.

- A szexuálisbün-elkövetőként meghatározott egyén a továbbiakban a szabadulása utáni feltételezett magatartása felöl nézve kerül az érdeklődés középpontjába. Mind a múltbéli tettei, mind a jelenlegi magatartása kizárólag a hipotetikus jövő irányából nyerik el az értelmüket.

- A sex offender életrajza az első terápiás beavatkozástól, vagyis a felméréstől kezdődően újraíródik. Korábbi életeseményei vagy személyiségének jellegzetességei immár kockázati tényezökként definiálódnak - így lesz például a gátlásosságából a társas elutasítottság visszaesést elörevetítő veszélyjelzője, gyakori szomorúságából pedig a negatív emocionalitás rizikófaktora. Az ismerősökre, a családra, a barátokra ugyancsak kockázati tényezőkként vagy „támogató csoportokként” hivatkoznak a továbbiakban.

- A személyiségvonások gazdag készletéből egyedül a programmal és a tekintélyszemélyekkel való együttmüködés, illetve a terápiára különösen veszélyes manipulációt mutató pszichopátia válik fontossá.

A tesztvizsgálatokat követően a fogvatartottak három alkalommal úgynevezett bevezető kognitív pszichológiai órákon vesznek részt, amelyek anyagát külön dossziékban, fénymásolt papírlapokon is megkapják. A felkészítés célja a bünelkövető szocializációja: azáltal, hogy már a kezdeti időszakban elsajátítja a program nyelvét és az életesemények kognitív keretben történő újrastrukturálásának módját, világossá válik számára, hogy a terápia nem egyszerủen „megfelelő magaviseletet” vagy puszta önkontrollt, hanem a korábbitól gyökeresen eltérö élettörténeti narratívumok elkészítését, az én új technológiáit ${ }^{8}$ követeli meg tőle. A felkészítő szakasz filozófiájának fontosabb jellemzői a következők:

- Az elítéltek a Program alapelvei című dokumentum első pontjában találkoznak a következő kijelentéssel: „Elsődleges feladatom, hogy önmagamon dolgozzam. A kezelés célja, hogy NE TEGYEK TÖBBÉ ÁLDOZATTÁ MÁSOKAT". Korábban már említettem, hogy a terápia elsősorban a civil közösség védelmét szolgálja - a programpont azonban valami másra is rá-

7 Vö. Uo.

8 Michel Foucault: Technologies of the Self. In: Luther H. Martin - Huck Gutman - Patrick H. Hutton (eds.): Technologies of the Self. Tavistock, London, 1988 
világít. A fogvatartottnak a következő hónapokban dolgoznia kell. A programmal való együttmüködés, az önmagán végzett kemény munka válik a legfontosabb feladatává. Ennek következtében - a normál körleteken elhelyezettekkel ellentétben - a kezelt kliensek nem tölthetnek be fizetésért végezhetö intézeti állásokat - ahogy az többször is elhangzott a terapeuták szájából: „Az önök munkája a program”.

- A treatmentnek mint a „személyiséget célzó több hónapos munkavégzésnek" a metaforájából következően a fogvatartott énje elrontott, selejt munkadarabként íródik újra. Ahogy az Alapelvek címü írás fogalmaz: „, A legsúlyosabb problémám: Azt akarom, amit én akarok, és akkor, amikor én akarom." A hibás személyiséget a probléma azonosítása után fáradságos munkavégzéssel lehet csak helyreállítani. Mivel a bajok okozója az ,én akarom" mentalitás - vagyis a személy problémája a személyiség maga -, a megoldás természetesen a „régi én” totális megsemmisítése: „A csoportmunka fókusza, hogy megtanuljam megkérdöjelezni a gondolataimat, érzéseimet és viselkedésemet."

- A kliensnek a „régi én” megsemmisítése érdekében teljes mértékben át kell adnia magát a terápiának. Noha a program elsősorban az egyéni választást hangsúlyozza, a kooperáció alapvetően akkor sem választás kérdése, ha az önalávetés kötelessége a lehetőségek terminusaiban fogalmazódik újra: „Két választási lehetöségem van: vagy a felépülésemet választom, vagy azt, hogy ugyanaz maradok, aki voltam.” Utóbbi esetben természetesen a „régi énnek" járó következményekkel kell szembesülnie: meghosszabbított börtönbüntetéssel, bizonyos büncselekmények esetében pedig a szexuálisan eröszakos ragadozó (Sexually Violent Predator; SVP) részlegbe helyezéssel. (Az SVP már nem a büntetés-végrehajtási szervezet irányítása alatt áll. Azok a bünelkövetők, akik egy szakértői bizottság és a bíróság ítéletének értelmében helyreállithatatlanul veszélyesek, a börtönbüntetésük letöltése után ide kerülnek. Fennállása óta az SVP-ből senki sem került vissza a civil közösségbe.)

- Ahogy a hibás munkadarab kijavítása időigényes folyamat, jól körülhatárolható lépésekkel, úgy a károsodott személyiség helyreállításának is megvan a maga forgatókönyve. Az ehhez szükséges lépéseket bemutató dokumentum szerint a büncselekménnyel összefüggő problémák (kontrollvesztett, felelőtlen, másokat bántó viselkedés) öszinte beismerése után a lelkiismeretes önvizsgálatot az élet valamennyi területére ki kell terjeszteni. Meg kell szabadulni a kifogásoktól, és megérteni a káros viselkedések következményeit. A későbbiekben a megbánás és az áldozat iránt érzett empátia el kell hogy ve- 
zesse a klienst az egészséges és másokat áldozattá nem tevő kapcsolatok kialakításához (hogy őszinte, felelősségteljes viszonyba léphessen másokkal a civil életben is, és „ennek üzenetét” embertársainak is átadhassa). Érdekes módon azonban a dokumentum címe nem „A kiegyensúlyozott és egészséges élethez vezetö út", hanem Lépések a szexuálisbün-elkövetö felelösségének elismeréséhez, vállalásához.

- Mindezzel kapcsolatban fontosnak tartom Waldram ${ }^{9}$ megállapításait idézni, aki szerint a szexuálisbün-elkövetőket célzó programok esetében értelmetlen rehabilitációról beszélni. Egyfelöl, sok esetben hiányzik egy olyan pont az elkövetö múltjából, amelynek helyreállítását a kezelés célba vehetné (vagy ha lenne is ilyen életszakasz vagy személyiségállapot, a „sex offender” stigmája a közösségben gondoskodna arról, hogy a problémamentes visszatérés ne valósulhasson meg a jövőben). Másfelöl, a treatment hosszú hónapjait tanulmányozva Waldram célszerübbnek látta a habilitáció terminus bevezetését a terepmunka-tapasztalatainak értelmezésekor. Véleménye szerint ,, a habilitáció annak a folyamata, hogy mindazt megteremtsük másokban, amit a legjobban értékelünk erkölcsi, etikai és társas szempontokból. Az a fajta moralitás, amit a sex offender programban alkalmaznak, egy ideális, nem túlságosan árnyalt, minden ambivalenciától mentes erkölcsiség, amely tartalmazza a börtönprogram által proszociálisnak hivott viselkedést is - ami az emberi társadalom természetének utópikus elképzeléseiböl eredeztethetö."

- Végezetül a résztvevők kézhez kapják a kognitív torzítások, gondolkodási hibák és taktikai játszmák jegyzékét is, amelyek által a kezdetektől nyilvánvalóvá válhat számukra, hogy a program fókusza a gondolatok mindenre kiterjedő, tüzetes vizsgálata lesz a további hónapokban.

A program bevezető szakaszának tétje, hogy megvalósítható-e a fogvatartottnak a kezelésre alkalmas személlyé történő átalakítása néhány hét alatt. Sikerül-e a gondolkodási hibáit, vagy legalább az azokat fenntartó makacsságot, az „önigazoló meggyőződéseket” olyannyira fellazítani, hogy kezdetét vehesse a személyiség mélyére hatoló terápia? Akik elfogadják a szexuálisbün-elkövetők - mind a normál börtönközösségekben, mind a civil életben megbélyegző, veszélyes - címkéjét, és elismerik a büncselekmény elkövetését, átköltözhetnek a program második szakaszának otthont adó épületbe,

9 James B. Waldram: i. m. 11. o. 
ahol kezdetét veszi az intenzív munka. A terápiának a továbbiakban részletesen bemutatandó alapelemei, röviden összefoglalva a következők:

- Az elítélt számára érkezéskor kijelölnek egy a programban már több hónapja részt vevő társat (big buddy), aki nemcsak a szabályokat ismerteti, de afféle mentorként problémák vagy akadályok felbukkanása esetén tanácsokkal is ellátja az újoncot.

- A fogvatartottak a kezelés második szakaszában a terápiás közösség (therapeutic community; TC) demokratikus szabályai szerint élnek együtt: ez nemcsak azt jelenti, hogy a felvetődő nehézségeket heti rendszerességü, a mindennapi élet kérdéseinek megvitatására szánt csoportfoglalkozásokon oldják meg, hanem azt is, hogy a résztvevők felelősek egymás terápiás fejlődéséért. Az alapelvek bemutatásánál már említettem, hogy a program ,, $a z$ egészséges és másokat áldozattá nem tevő kapcsolatok kialakitása" képességének megteremtését is célként határozza meg. A TC-ben a fogvatartottak nem csupán a helyes/követendő és a helytelen/elítélendő magatartás példáit jelenítik meg egymás számára, de afféle gyakorlóterepet is szolgáltatnak a többieknek a ,proszociális” viselkedésformák elsajátításához.

- Egy korábbi terepmunkám helyszínéül szolgáló maximális biztonságú börtön terápiás közösségével összevetve a szexuálisbün-elkövetők TC-szabályzata nem a család metaforáját használja a résztvevők közötti kapcsolatok létrehozására és megerősítésre. Míg az Intenzív terápiás közösség fogvatartottjai testvérekként és családként hivatkoztak önmagukra, és a keresztneveiken szólították egymást, addig a szexuálisbün-elkövetők az alacsonyabb fokú érzelmi bevonódást implikáló közösség és barát (lásd például a big buddy kifejezést) terminusokat használják (és kizárólag Mr. X. Y.-ként szólhatnak a társaikhoz, vagy hivatkozhatnak egymásra). Mindez valószínüleg a „manipulatív” szexuálisbűn-elkövetők között kialakuló, túlságosan szoros, intim - esetleg könnyen „szexualizálódó” - kapcsolatok létrejöttének fenyegetésétől kívánja megóvni a csoportot. Másfelől számol a stigmatizáció jelenségével is: azzal, hogy noha a résztvevők egyaránt szexuálisbủn-elkövetőkként hivatkoznak magukra, sokan közülük ellenkeznének, ha a családtagoknak kijáró megnevezésekkel kellene illetniük egy olyan bűnelkövetőt, akinek a büncselekményét a program elvárásai ellenére is mélyen megvetik.

- Az újonnan érkezett kliens részére a kijelölt terapeuta negyedéves tervet készít (majd három hónap elteltével egy-egy újabbat a programban való haladásnak és az időközben napvilágra kerülő problémáknak megfelelően). Ebben a korábbi felmérés eredményei alapján célokat határoz meg, ame- 
lyekhez a kockázati tényezöket csökkenteni kívánó feladatokat rendel hozzá. A fogvatartott elöírt teendői egyfelől a hétköznapi viselkedésére vonatkoznak (például: „Mr. Morton a következő hónapokban beszélgetést kezdeményez a társaival" - abban az esetben, ha Mr. Morton rizikófaktorai között a társas elutasítottság szerepel). Másrészt, a terapeuta a kognitív viselkedésterápia elveinek megfelelő - elsősorban a gondolkodási hibák és diszfunkcionális mintázatok azonosítását célzó - esszéfeladatok elkészítését javasolja (például: „Mr. Morton fogalmazást ír »Milyen veszélyeket jelent számomra a gátlásosság?« címmel”).

- Az elítéltek heti kétszer úgynevezett primary csoportokon vesznek részt. Az alkalmanként háromórás, 15 fö részvételével zajló csoportfoglalkozásokon a programban történő elörehaladásukat vitatják meg. Ezeken a TC-csoportoknál jóval intenzívebb érzelmi bevonódást igénylő foglalkozásokon kerül sor a házi feladatok bemutatására és értékelésére is.

- A program kilenc-tizenkét hónapja alatt a fogvatartottnak először egy vázlatot kell készítenie a fontosabb társas kapcsolatairól (Brief Social History), majd be kell számolnia mindazokról a személyekröl, akik ellen valamilyen szexuális jellegü büntényt követett el (Sexual Victim Disclosure). Utóbbi esetben nyomatékosan felhívják az elítélt figyelmét arra, hogy azokat az áldozatokat is említse meg, akik nem tettek feljelentést (ugyanakkor arra is megkérik, hogy lehetőleg ne adjon az áldozat azonosítását lehetővé tevő információt, máskülönben a terapeutának feljelentést kell tennie).

- A program három fö pillére egy hosszabb, a kezelés elvárásainak megfelelö önéletrajz (Autobiography) megírása, a konkrét büncselekmény kognitív keretben történő részletes elemzése (Case report), valamint a szabadulás előtt a visszaesés megelőzését szolgáló terv (Relapse Prevention Plan) elkészítése. A hosszabb írásbeli munkákat általában a primary csoport valamennyi tagja elolvassa, majd pedig közösen értékelik.

- A fogvatartottnak a program befejezését megelőzően az áldozat iránti empátiájáról is tanúbizonyságot kell tennie (Victim Empathy Exercise). A többi feladattal ellentétben ebben az elsősorban érzelmi beleélö képességet igénylö, dramatikus helyzetben az elítéltnek az áldozat szemszögéből kell elmesélnie a történteket.

- Míg a primary csoportban megvitatott feladatok a fogvatartott terápiás közösségen kívüli életét, illetve a múltat és a jövőt célozzák, addig a terápiás nagycsoport a jelenre, az itt és mostra fókuszál. A terapeuták vezetésével zajló eseményen egy adott szárny valamennyi fogvatartottja részt vesz (60 fö, illetve az adott szárnyért felelös két vagy három terapeuta). Noha a 
nagycsoport egyik fő célkitüzése a mindennapos problémák közös megvitatása és megoldása, tapasztalataim szerint jóval erősebb hangsúly esik a foglalkozás „egyéni felelösségre vonások” programpontjára, amikor az egyes fogvatartottak a közösség színe elött ismerik el a hibáikat. A közösségi együttélést segítő csoportok célja elsősorban az aktuális viselkedésnek a büncselekményhez, illetve a jövőbeli kockázatokhoz való kapcsolása.

- Noha a program az „egészséges kapcsolatok” előmozdítására törekszik, a „manipulatívnak” és „önigazolásra törekvőnek” tartott szexuálisbün-elkövetők közötti spontán, szimpátia alapján létrejövő barátságok „gyanúsak”. Annak érdekében, hogy a fogvatartott valóban szakíthasson a régi énjével, a korábbi társas mintái alapján történő barátválasztásokat is kontrollálni kell. A kontrollt egyfelől azáltal valósítja meg a személyzet, hogy minden egyes fogvatartottnak kijelöli a fekhelyét a hatvan férőhelyes hálóteremben ('́gy teljesen esetleges, hogy kinek kik lesznek a szomszédjai, vagyis kikkel osztja meg a közvetlen környezetét). Másfelől, a terapeuták úgynevezett támogató csoportokat hoznak létre. Minden résztvevő négy másik, a személyzet által kijelölt fogvatartott support groupjának a tagja; az ily módon létrejövő ötfős támogató csoportok heti rendszerességgel ülnek össze annak érdekében, hogy elősegítsék a fogvatartott aktuális problémáinak hatékony megoldását. A támogató csoportok egy újfajta, mesterséges hálózatot hoznak létre a közösségen belül, hiszen gyakran olyan emberek vitatják meg a legszemélyesebb gondjaikat - csoportonként minimum 45 percben -, akik egyébként esetleg szóba sem álltak volna egymással.

- Mint már említettem, a program elsősorban a kognitív pszichológia bizonyitékokon alapuló, azaz tudományos kutatásokkal is alátámasztott eredményeire épít. Alapelve, hogy a hibás viselkedés elsősorban gondolkodási torzítások következménye, ezért a terápia célja a „nem megfelelő” hiedelmek azonosítása és korrekciója. Mivel a kezelés a gondolkodás folyamatára és a gondolatok tartalmára fókuszál, talán nem meglepő, hogy a Sex Offender program foglalkozásainak jelentős hányada edukativ jellegü, és leginkább a tantermi előadásokhoz hasonlít. A fogvatartottak tankönyveket kapnak „A harag megfelelő kezeléséről”, „Az egészséges kapcsolatokról és szexualitásról”, „A bünözői gondolkodásról”, „Az egészséges kommunikációról és a határokról”, „Az érzelemmenedzselésről”, ezeket heti két alkalommal két-három órás pszichoedukációs foglalkozásokon dolgozzák fel a terapeuták vezetésével.

- Az intézet szabályai ellen vétők közül azok, akik olyan súlyú cselekmény(eke)t követtek el, hogy a felügyeletnek (custody staff) a fogdára kellett helyez- 
nie őket, automatikusan kikerülnek a programból. A felfüggesztés másik lehetséges módja, ha valaki a terápiás szabályok ellen vét (érdektelen, nem készíti el időben a feladatait, nem múködik együtt a terapeutájával vagy a közösségben mutatott magatartása időről időre ismétlődő gondolkodási hibákat hoz a felszínre, amelyeken nem hajlandó dolgozni). A terapeuta által problémásnak ítélt fogvatartott a heti egyszer összeülő treatment team elé kerül (ebben dr. Moreno, a program szakmai vezetöje, egy nevelö és egy terapeuta foglal helyet). Ha a team úgy ítéli meg, hogy a fogvatartott magatartása olyan mértékben tanúskodik a kooperáció hiányáról, hogy a további terápiás próbálkozások kudarcra vannak ítélve, akkor az elítéltet kihelyezik a programból. Kevésbé súlyos, ,javítható” esetekben a fogvatartott írásbeli jóvátételi feladatokat kap, amelyeket néhány héten belül a terapeutájának kell átadnia.

A treatment struktúrájának bemutatását, a program alapfogalmainak és felépítésének tisztázását követően a továbbiakban a terápiás közösség etnográfiai vizsgálata segítségével igyekszem néhány problémás pontot megvizsgálni - elsősorban az esetelemzés és az áldozattal való azonosulás feladatainak részletes vizsgálatával -, amelyeken keresztül kirajzolódnak az egyén átalakítását célzó törekvések.

A bűncselekmény kognitív keretben történő elemzését megelőzően a fogvatartottaknak részletes önéletrajzot kell írniuk. A büncselekményhez vezetö ok-okozati összefüggések igazságának feltárását célzó önéletrajz az egyén totális felelösségének létrehozására törekszik:

- A feltételezett személyiségvonások a szövegben nem egyszerüen oksági tényezőkként jelennek meg az események értelmezésekor (például „Gátlásos voltam, ezért nem beszéltem senkivel”). A vonások birtoklásáért is az individuum válik felelőssé: az ö egyéni döntése, hogy az adott tulajdonságot elfogadja, ,megtartja”, vagy elveti-e.

- A program ezek szerint feltételez egy a létezésének minden pillanatában választani kényszerülő, tulajdonságok nélküli egót, amely az én (szelf) létrehozásakor tetszőleges karakterisztikumokkal ruházza fel azt. Foucault-i perspektívából nézve a Sex Offender program elsősorban ennek a szabad döntés birtokában lévő énnek a létrehozására törekszik. A fogvatartott élettörténetének újraírása azt a célt szolgálja, hogy az egyén ennek a választásokért felelős egónak a létezését kora gyerekkorától kezdődően a saját múltjában felismerje.

- Mivel a Sex Offender program mindvégig óriási hangsúlyt helyez az „igazságra”, az önéletrajzok prezentálását követő konklúziók nem „értelmezési 
modellekként", hanem megfellebbezhetetlen tényekként állnak a résztvevők előtt, akik a kezeléssel való további együttmüködés érdekében kénytelenek elfogadni a múlt újonnan elóállított „valóságát” a sajátjukként.

\section{Esetelemzések}

A Sex Offender program résztvevője a bemutatkozás, illetve a Brief Social History és az Autobiography elkészítése során sex offenderré alakul át. A fogvatartott immár bünözőként, a ,veszélyesség magvát magában hordó életrajzi egységként”'10 áll előttünk arra várva, hogy a „büntető-nevelő tudomány” tovább folytathassa a „megjavítását”. A Case report látszólag továbbra is a múltra, a büncselekmény elkövetésére koncentrál, azonban a továbbiakban látni fogjuk, hogy a kognitív viselkedésterápia elméletének felhasználásával hogyan terjeszti ki a büncselekmény idejét a jelen, illetve a jövő időre is.

A Case reportok ${ }^{11}$ elkészítése során a fogvatartottnak a kognitív elmélet „bünelkövetés-ciklusának” keretébe illesztve kell „konceptualizálnia” a történteket. A körfolyamat vázlata - amit a program résztvevői segédanyagként kézhez kapnak - a következő (ábra).

A kognitív modellt alaposan szemügyre véve a következő problémákkal találkozhatunk:

- Mivel a szexuálisbün-elkövetők visszaesési mutatói meglehetősen alacsonyak az egyéb büncselekménytípusok elkövetőiéhez képest ${ }^{12}$, feltételezhető, hogy a Sex Offender program résztvevőinek jelentős része első büntényes. Noha arról nincsenek adataim, hogy a fogvatartottak hány százaléka követett el folytatólagosan bủncselekményeket, a Waldramtól származó következő idézet megvilágítja, miért válik az egyetlen áldozatú szexuálisbün-

10 Michel Foucault: Felügyelet és büntetés. Gondolat Kiadó, Budapest, 1990, 344. o.

11 Vö. William Marshall - Dana Anderson - Yolanda Fernandez: Cognitive Behavioral Treatment of Sexual Offenders. John Wiley and Sons, New York, 1999; Harvey Milkman - Kenneth Wanberg: Cognitive-Behavioral Treatment. A Review and Discussion for Corrections Professionals. U.S. Department of Justice. National Institute of Corrections, Washington, D.C., 2007

12 Az Egyesült Államok igazságügyi minisztériuma 2002-ben készült átfogó felmérése szerint a szexuálisbün-elkövetők 5,3 százalékát tartóztatják le ismételten valamilyen szexuális jellegü büncselekmény miatt (ha a nem szexuális jellegü cselekmények miatti letartóztatások adatait nézzük, ez a szám már 43 százalék). A nem szexuális cselekmények miatt elítéltek visszaesési mutatói jóval magasabbak: 68 százalékukat tartóztatják le ismét szexuális vagy nem szexuális jellegü büncselekmény miatti vádak következtében. Patrick A. Langan - Erica L. Schmitt - Matthew R. Durose: Recidivism of Sex Offenders Released from Prison in 1994. U.S. Department of Justice, Office of Justice Programs, Washington, D.C., 2003 


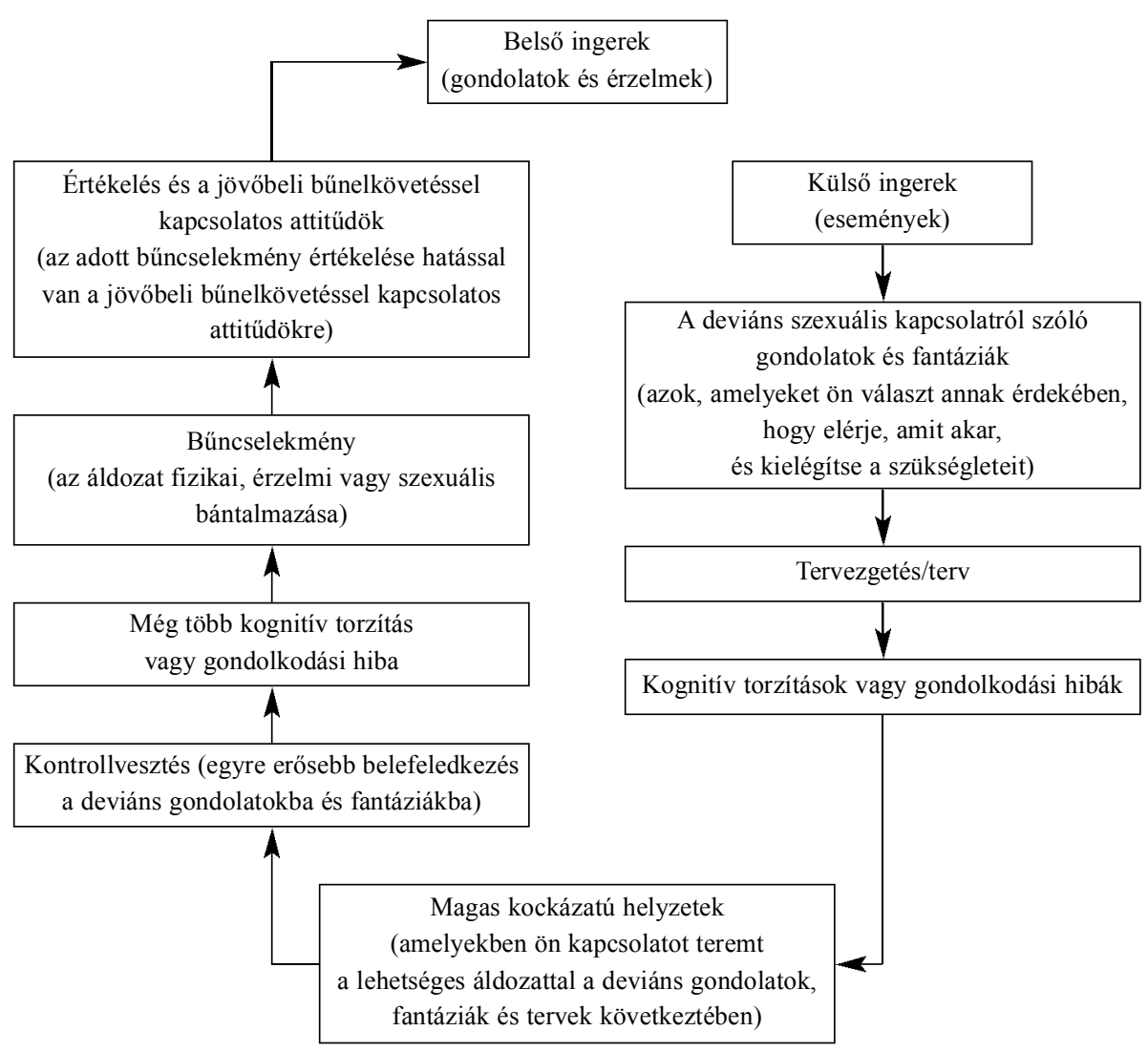

elkövetők számára problémássá a bűnelkövetés körmodellje: „A kognitív esetkonceptualizálás feltételezi, hogy a klienseknél képesek vagyunk mintázatokat azonositani az újbóli bünelkövetések során. Azokkal azonban igazán nehéz dolgunk van, akik egyetlenegy cselekményt követtek el. Náluk az életstílus egészét próbáljuk megvizsgálni."

- A bünelkövetés ciklikus modellje tehát lényegében „bünözőt” farag a „bűnelkövetőből”, és jövő időt formál a múltból. A feltételezett „deviáns fantáziákkal" és kognitív torzításokkal bíró sex offender megalkotása után immár logikusnak tünik, hogy a személy - épp a személyiségéből fakadó hibák miatt - újból és újból belép majd a körfolyamatba (a Sex Offender program pedig a gondolkodás megváltoztatásával az ördögi kör megtörését ígéri). 
- A séma alapján az is nyilvánvaló, hogy a modell nehezen tud mit kezdeni azokkal a bünelkövetőkkel, akik elmondásuk szerint a ,pillanat hatása alatt”, impulzívan cselekedtek, elözetes tervek nélkül. Esetükben vagy a „gyorsan átsuhanó gondolatok” utólagos rekonstrukcióját kell megkísérelni, vagy az életstílus egészében kell azonosítani a „meggondolatlanságot” és a „tervezés hiányát" mint rizikófaktorokat.

- Hasonlóképpen: azok, akik azt állítják, hogy drog vagy alkohol hatása alatt egyáltalán nem voltak a tervezés képességének birtokában, vagy megpróbálják a modellnek megfelelően átalakítani az eseményeket a visszaemlékezés során, vagy a teljes élettörténetükben azonosítják azokat a „deviáns fantáziákat” és „gondolkodási hibákat”, amelyek a bünelkövetés idején a felszínre bukkantak. Mind az impulzívak, mind a szerhatás alatt állók esetében kérdéses, hogy az ily módon létrejövő narratívumok mennyire állnak összhangban mindazzal, amit a fogvatartott tapasztalt, vagy amire visszaemlékezni képes: hogy az ,igazságnarratívumoknak” van-e bármi közük az elítélt „,igazságához”.

- Érdekesek azok az esetek is, amelyeknél egyértelmű, hogy a kockázati tényezők többé nem állnak fenn (a kérdés tehát az, hogy hogyan faragjunk jövő időt egy véglegesen meghaladottnak tủnő múltbeli állapotból). Mr. Morris például, akit 16 évesen borzasztóan zavart, hogy még sohasem volt barátnője vagy szexuális kapcsolata, egy alkalommal zaklatta (intim testtájakon megsimogatta) a tízéves unokahúgát. Nem sokkal ezután sikerült leküzdenie a gátlásosságát, és kialakított egy hosszú távú kapcsolatot is. Elmondása szerint sem a bünelkövetés idején, sem azóta nem gondolt gyermekkorú lányokra erotikus fantáziálás közben. A börtönbe kerüléséig tartó, szabadlábon töltött időszakban barátokat szerzett, és „egyéjszakás kalandjai" is voltak. Amikor a Case report bemutatását követően a kockázati tényezőit kellett volna azonosítania a visszaesés megelőzése érdekében, nem tudott mit válaszolni a terapeuta kérdésére. Azt mondta, biztos abban, hogy sohasem fog ilyen cselekményt elkövetni. Ekkor kapott egy listát, hogy „valamit válasszon”. „Rendben - felelte -, talán a párkapcsolati labilitás és az unalom lehetnének veszélyesek." A választ elfogadta ugyan a terapeuta, a helyzet iróniája azonban az, hogy az elkövetés időszakában Morris legnagyobb problémája épp az volt, hogy nemhogy ,párkapcsolati labilitást" nem élhetett át, de semmilyen párkapcsolatot nem volt képes kialakítani.

- A kognitív modellben ismételten találkozhatunk azzal a feltételezéssel is, hogy a szexuálisan „deviáns” fantáziák és gondolatok választás következ- 
tében jönnek létre. Ily módon azoknak a fogvatartottaknak a tapasztalatai, akik azt állítják, hogy „képtelenek elérni az orgazmust” egyéb, nem normasértő fantáziák segítségével, kiszorulnak abból a problématartományból, amit a modell magyarázni képes (pontosabban: úgy kell átalakítaniuk az élményeiket, hogy azok a „kötelező szabadság és választás” eszméjéhez igazodjanak).

A számomra legmegdöbbentőbb esetek azonban nem egyszerüen a kognitív körmodellhez, hanem az áldozathoz való viszony jellegéhez kapcsolódtak.

Egy meglehetősen zárkózottnak tủnő fogvatartott, Mr. Walsh a büncselekményének ismertetésekor elmondta, hogy átkopogott a szomszéd nőhöz, akitől kölcsön akart kérni valami apróságot. Amikor a nő a hálószobájába ment az említett tárgyért, Walsh megpróbálta átölelni, majd egyre erőszakosabban szexre kényszeríteni. A nő végül ellökte magától, így Walsh nem próbálkozott tovább, hanem hazament.

Az elítélttársak kérdéseire válaszolva elmondta, hogy - mivel a nő a szomszédjában lakott - többször látta az ablakon keresztül, hogy az élettársa súlyosan bántalmazza. A kijelentést követő kérdés ekkor arra vonatkozott, hogy vajon nem azért támadt-e a szomszédjára, mert látta, hogy ezzel a nővel így bánnak, vele „megengedhető” az erőszakos viselkedés is, így feljogosítva érezte magát arra, hogy ő is hasonlóképpen cselekedjen. Walsh azt felelte, hogy neki ez sohasem jutott még eszébe, bár, ha a többiek így látják, lehet, hogy ez is része az esetnek. Ő legtöbbször inkább arról álmodozott, hogy megmenti a nőt, aki ezért ,jutalomból” vele létesít majd szexuális kapcsolatot, vagy elhagyja az élettársát, és az ő barátnője lesz. Ez a pozitív érzelmekre összpontosító interpretáció a továbbiakban már egyáltalán nem került szóba, inkább a fogvatartott feltételezett nőgyülöletére koncentráltak a csoporttagok.

Walsh példája világosan mutatja, hogy a program nehezen kezeli az ambivalenciát. Azokban az esetekben, amelyekben egyértelmüen erőszakos a büncselekmény, többnyire fel sem vetődik, hogy az elkövetőt nem feltétlenül - vagy nem kizárólag - a gyülölet és a manipuláció szándéka vezetheti, így a visszautasított motívumok hamar ki is rekesztődnek a történet rekonstrukciója során. Még érdekesebbek azok a helyzetek, amelyekben erőszakról sincs szó:

Egy másik alkalommal Mr. Smith olvasta fel a Case reportját. A büncselekmény, amely miatt letartóztatták, az volt, hogy tizenhét éves korában egy szombat esti parti után szexuális kapcsolatot létesített az akkor tizenhárom 
éves barátnőjével. Az eseményeket nagyon meghittnek és kölcsönös beleegyezésen alapulónak írta le. A terapeuta kissé ironikusan meg is jegyezte, mennyire hangsúlyozta Smith a romantikus ábrázolást.

Az eset ismertetését követő kérdések elsősorban arra irányultak, hogy Smith „manipulatív természetét” alátámasszák, illetve megalkossák. „Azt mondtad az imént - kezdte az egyik elítélt -, hogy sohasem voltál eröszakos és manipulatív. Ha ez igaz, akkor mégis hogy vetted rá az áldozatot, hogy levesse a ruháit? " A csoportfoglalkozás következő fél órája azzal telt, hogy bebizonyítsák Mr. Smithnek, hogy a „rafináltsága” lényege az volt, hogy olyan helyzetet teremtett, amelyben a lány végül maga mondta ki, hogy szeretne szeretkezni vele. Smith Case reportjának konstrukciója során mindvégig az az érzésem volt, hogy annak érdekében, hogy a lányt áldozatnak lehessen tekinteni, szükség van az elkövető mint „manipulátor” alakjára. A cél egy olyan narratíva létrehozása volt, amelyben az áldozat azért áldozat, mert a szabad akaratától fosztják meg akkor is, ha a saját vélekedése szerint szabad akaratából cselekszik. Az áldozatok és az elkövetők viszonyát a következő programfeladat, a Victim Empathy Exercise alapján mutatom be részletesen.

\section{Az áldozathoz füződő viszony: Victim Empathy Exercise}

Mr. Reim nagyot nyelt, amikor a terapeuta megkérte, hogy az aznapi primary csoportban mutassa be a Victim Empathy gyakorlatot. A fogvatartott tiltakozni próbált mondván, hogy nem számított erre, de Amy, a terapeutája megnyugtatta: a szerepjáték nem igényel különösebb tudatos felkészülést. A lényeg, hogy koncentráljon néhány percig csendben, próbálja meg elképzelni, hogy ő maga az áldozat, és mesélje el a lány szempontjából a történteket. ${ }^{13}$

Mr. Reim a harmincas évei elején járt, amikor a feleségével kezdett megromlani a viszonya. A nő nem ment el vele sehová munka után, és a hétvégéken is inkább otthon maradt. A szexuális kapcsolat megszünt kettejük között, egy idő után pedig nem is beszélgettek többé. Ezzel párhuzamosan Reim

\footnotetext{
13 Amint azt Waldram is megjegyzi (James B. Waldram: i. m. 194. o.), a Victim Empathy gyakorlatban a büncselekmény specifikus részletei már nem jelennek meg (azaz a konkrét cselekvéseket a fogvatartottak nem részletezik olyan alapossággal, mint a Case reportok prezentálásakor). A szerepjáték során inkább az áldozat pszichés és fizikai szenvedésére helyeződik a hangsúly, a bünelkövető gondolatai és érzései itt nem kerülnek szóba. Jellemzően ez az a feladat, amelyet a legkevesebben kommentálnak, illetve itt a legkevésbé kritikusak a résztvevők.
} 
egyre közelebb került az akkor tizennégy éves nevelt lányához, Vickyhez. Együtt jártak koncertekre, vacsorázni, moziba, végül Reim - eleinte csak mintegy véletlenül, később már a szándékosságot is vállalva - simogatni kezdte a lányt, végül két éven át szexuálisan zaklatta.

A primary csoportban Reim a néhány perces némaság után felemelte addig lehajtott fejét, aztán halkan belekezdett a szerepjátékba: „Jó napot kivánok, Vicky vagyok. A mostohaapám tizennégy és tizenhat éves korom között szexuálisan molesztált."

A továbbiakban a Reim által alakított „Vicky” elmesélte, hogy amikor az édesanyja egyre jobban eltávolodott a mostohaapjától, ő furcsa módon közelebb került Reimhez. Egyszer az egyik közös koncertlátogatásukat követően, amikor a szobájába indult a lépcsőn, a férfi hátulról megsimogatta. Ő zavarba jött, igyekezett elviccelni a dolgot, de ettől a naptól kezdődően a mostohaapja esténként megjelent a szobájában. Először csak ruhán keresztül simogatta, később szexuálisan is zaklatni kezdte. „Vicky” elmondta, hogy kezdetben azt hitte, valamiféle „különleges kapcsolat” van kettejük között, de később rájött, hogy Reim csak ,használta” őt. Az eset szörnyen megviselte, megszégyenült az orvosi és rendörségi vizsgálatok során, a szomszédok és az iskolatársai előtt, és úgy érzi, sohasem fog helyreállni benne az a bizalom és jóhiszemüség az emberek iránt, ami korábban jellemezte.

A Reim által konstruált áldozattörténet - illetve maga a Victim Empathy gyakorlat általában - számos problémát felvet:

- Elöször is kérdés, hogy az áldozat életének melyik periódusából, vagyis milyen nézőpontból hangozzon el a történet. Akadnak fogvatartottak, akik kénytelenek gyermekkorú áldozataik szerepébe helyezkedni, és a bemutatkozáskor például azt mondani, hogy „Mary vagyok, kilencéves”. A perspektíva problémája azért fontos, mert - ahogy arra Clancy $^{14}$ kutatásai is rámutatnak - az áldozatok idősebb korban újrakonceptualizálják a történteket. Amit az események idején még nem fogtak fel, az később érthetővé válik számukra. Mindezek miatt azoknak, akik igen fiatal gyerekek szerepét öltik magukra, el kell szakadniuk az életkornak megfelelő történet megszerkesztésétől, és úgy kell beszélniük, mintha az áldozat már az elkövetés pillanatában tisztában lett volna azzal, hogy valamilyen traumatikus eseményt él át (máskülönben nem tudnák bizonyítani a terapeutának, hogy tisztában vannak a cselekedeteiknek az áldozatra gyakorolt hosszú távú, szörnyủ hatásaival).

14 Susan A. Clancy: i. m. 
- Clancy szerint ${ }^{15}$ ugyanakkor a gyermekkorú áldozatok elsősorban zavart és értetlenséget tapasztalnak a zaklatás idején. Jóval később, amikor megértik a szexualitás jelentőségét, megváltozik számukra a korábban „furcsának” tünő események jelentése is. Sokan közülük becsapottnak kezdik érezni magukat: olyannak, akinek a bizalmával visszaéltek, akit kihasználtak. Megkérdőjelezik néhány alapfeltevésüket is arról, hogy szerették-e őket egyáltalán valaha. Mivel - az események megértése hiányának következtében - nem tanúsítottak ellenállást, elfogadták az ajándékokat, nem utasították vissza az elkövetőt, önmagukat hibáztathatják a történtekért.

- Amint arról korábban szó esett, a Sex Offender program nehezen kezeli az ambivalenciát. Reim például egyfolytában arról beszélt Vicky szerepében, hogy a mostohaapa ,áldozattá tette”, „kihasználta”, „manipulálta” őt. Bár ebben a történetben többé-kevésbé megjelent, hogy Vicky bízott benne és kedvelte a férfit, az áldozat ellentmondásos érzelmei nem kaptak hangot. „Vicky” nem beszélhetett például arról, hogy a Reimtől kapott ajándékok elfogadása, és az ezekért „cserébe” nyújtott szexualitás miatt esetleg büntudatot érez, vagy szégyelli magát (ahogy azt Clancy az áldozatokkal készített interjúk alapján leírta). Vicky ambivalens érzelmei ugyanis egyértelmüen arra vonatkoztak volna, hogy Reim kisebbíteni igyekszik a saját felelősségét (ha Vicky szerepében Vickyt okolta volna, az az áldozat hibáztatásával vált volna egyenértéküvé).

- Ebben az esetben viszont kérdéses, hogy „kinek az igazsága” jön létre az „áldozatnarratívumok” konstrukciója során. Az elkövetők egy része, akik a program elvárásainak megfelelően kénytelenek az áldozat szerepében tiltakozásról, félelemröl, fájdalomról beszélni akkor is, ha az elkövetés pillanatában ök maguk esetleg inkább együttmüködést tapasztaltak, könnyen arra a következtetésre juthatnak, hogy talán mégsem okoztak semmiféle kárt, és csak a program kedvéért kell „traumáról” beszélniük. Azt a jelenséget, hogy a szexuális zaklatás elszenvedése sokszor nem az elkövetés idején, hanem később, az újrakonceptualizálás során válik traumatikussá, a Victim Empathy gyakorlat nehezen képes kezelni (hiszen képtelenség az áldozat szerepét játszva egyszerre két, különbözö életkorhoz köthető énállapotot felölteni).

- Egy, szintén az „igazságot” érintő probléma vetődik fel azoknak az internetes büncselekményeknek az esetében is, amelyek elkövetése után kiderült, hogy egy fiatal lány helyett valójában egy nyomozó ült a másik számí-

15 Uo. 
tógép előtt. Mr. Wood például kemény kritikát kapott a primary csoportjának tagjaitól, amiért a Victim Empathy gyakorlat során nem tủnt elég érzelmesnek és együtt érzőnek. Cindy, a terapeutája úgy döntött, hogy a fogvatartottnak a következő alkalommal meg kell ismételnie a gyakorlatot. „De hát kit alakitsak? - kérdezte Wood. - Az ügynököt?” A terapeuta erre azt válaszolta, hogy azt kell eljátszania, aki traumatizálódott. A nyomozó nyilvánvalóan nem traumát élt át, hiszen ö, Cindy is nap mint nap hallja ezeket a történeteket, mégsem szenved el súlyosabb pszichés károsodásokat. Azt a feltételezett lányt kell eljátszania, aki a vonal túlsó végén ülhetett volna. Később megkérdeztem Cindyt, hogy mégis meddig kell elvinniük a történetet ilyen esetekben a fogvatartottaknak. Úgy kell játszaniuk, mintha a chateléssel véget ért volna a viszony? Vagy el kell képzelniük azt is, hogy esetleg találkoznak a „lánnyal”, és szexuális kapcsolat alakul ki közöttük? Nyilvánvaló ugyanis, hogy az, aki az áldozat szerepébe helyezkedik, egy lezárt történet felől nézve képzeli bele magát a „traumatizálódott” helyzetébe. Amikor azonban a történet nem valós, kinek áll jogában befejezést szerkeszteni a meg nem történt eseményekhez? A kérdéseimre nem kaptam megfelelő választ, Cindy annyit mondott csupán, hogy a fogvatartottra bízzák azt, hogy addig írja meg a történetet, ameddig a valóságban elvitte volna az eseményeket.

- További probléma, hogy az áldozat nincs jelen a Victim Empathy gyakorlat alatt, a bírósági végzések pedig tiltják, hogy az elkövetők kapcsolatba léphessenek velük. Ily módon megerősítés sem érkezhet arról, hogy sikerült-e a fogvatartottaknak átvenniük az áldozat nézőpontját, és belehelyezkedniük az érzelmi állapotába (jóllehet az empátia létrejöttének feltétele épp az, hogy megbizonyosodjunk arról, hogy valóban a másik ember lelkiállapotát és élményeit éljük át $\left.{ }^{16}\right)$. Egy fogvatartott Waldramnak ${ }^{17}$ azt mondta: ,, $a z$ egész nem más, mint puszta találgatás, hiszen honnan is tudhatnád, hogy érzi, vagy hogy érezte magát az áldozat”, különösen akkor, ha semmiféle visszajelzést nem kaphatnak tőle. Így azonban a Victim Empathy Exercise sokkal inkább büntetö jellegüvé válik: a bünelkövető nem alakíthat ki valódi empátiás kapcsolatot az áldozattal, nem hozhat létre vele egy közös narratívát, ami esetleg valamiféle megbékéléshez vezethetne ${ }^{18}$.

\footnotetext{
16 Lásd Buda Béla: Empátia. A beleélés lélektana. Folyamatok, alkalmazások, új szempontok. L'Harmattan Kiadó, Budapest, 2012

17 James B. Waldram: i. m. 184. o.

18 Uo. 195. o.
} 
A Victim Empathy Exercise büntető jellege domborodik ki az áldozatok és a bünelkövetők alakjának megalkotása során is. Az előző fejezet záró példájában láthattuk, hogy Mr. Smitht amiatt marasztalta el a csoport, mert képes volt úgy manipulálni a tizenhárom éves áldozatát, hogy az maga mondja ki, hogy szerelmes belé, és szexuális kapcsolatot szeretne létesíteni vele. A program szerint a büncselekmény lényege, hogy ilyen fiatal életkorban a személynek még nincsenek elegendő információi és megfelelő kognitív képességei a felelösségteljes döntés meghozatalához. Smith büne abban áll, hogy olyan feltételeket teremtett, amelyben az áldozat úgy érezhette, szabad akaratából dönt.

Mr. Rogers, egy újonnan érkező fogvatartott Amy primary csoportjában, a bemutatkozásakor beszélt arról, hogy tizenhárom évesen pornófilmeket nézett a nagyapjánál, aztán később, az éjszaka folyamán betörni indult. Bejutott egy házba, majd az értéktárgyak összegyüjtése után az ott alvó nőt megpróbálta megerőszakolni. A cselekmény miatt - az életkorára hivatkozva - nem börtönbe zárták, hanem egy speciális intézetbe, ahol egy programon kellett részt vennie. Amy ekkor arról kezdte faggatni, hogy volt-e szexuális viszonya az ott dolgozó személyzet tagjaival. Noha nemleges választ kapott, egymás után többször is feltette ugyanezt a kérdést, majd úgy fogalmazott, hogy „nem próbálta-e Rogers megkörnyékezni az ott dolgozókat”. Amikor a fogvatartott jelezte, hogy nem tudja értelmezni a kérdést, a többi elítélt sietett a segítségére: „Nem próbáltál-e csalással, manipulációval, hizelgéssel vagy bármilyen hasonló módon közel kerülni valakihez a program személyzetének tagjai közül?" Rogers határozottan tagadta, hogy ilyesmi történt volna, ahogy azt is, hogy bármelyikükről fantáziált volna maszturbálás közben. „,Ne haragudjon Mr. Rogers - válaszolta erre a terapeuta -, de nem hiszek magának. " Később azt is hozzátette, hogy véleménye szerint a szóban forgó éjszakán Rogers nem betörni indult, hanem azzal a tudatos szándékkal állt fel a pornófilmek mellől, hogy meg fog erőszakolni valakit.

Mr. Smith és Mr. Rogers történeteit egymás mellé helyezve láthatjuk, hogy a program ugyan nem feltételezi egy tizenhárom éves áldozatról, hogy szabadon döntene arról, hogy szeretne szexuális kapcsolatba lépni a tizenhét éves barátjával, miközben egy tizenhárom éves bünelkövetönek már képes a tudatos tervezés és a szabad döntés képességeit tulajdonítani. Véleményem szerint a terapeuták jóval kevésbé az életkorra, mint magára az áldozat- vagy bünözőszerepre koncentrálnak akkor, amikor a „szabad akarat” képességével, vagy annak hiányával ruházzák fel a különféle történetek szereplőit. Jó példát nyújtanak minderre azok az esetek is, amelyekben a program résztvevőiről derült ki, hogy tizenévesen szexuális kapcsolatot alakítottak ki valakivel. 
A fogvatartottak önéletrajzainak átolvasása közben nem egyszer találkoztam olyan történetekkel, amelyek igen korai szexuális élményekröl szóltak. Az egyik fogvatartott például tízévesen elégített ki egy tizenöt éves lányt, a kapcsolódó érzésekhez pedig azt írta: örömet, izgalmat, enyhe félelmet tapasztalt, és arra gondolt, hogy most már igazi férfi, hiszen van barátnője. Még beszédesebb volt Mr. Will önéletrajza, amelyben leírta, hogy tizennégy évesen vesztette el a szüzességét egy tizennyolc éves lánnyal, ami nagyon pozitív élmény volt számára. A későbbiekben kiderült, hogy amiatt került börtönbe, mert tizennyolc évesen szexuális kapcsolatot létesített egy tizennégy éves lánnyal.

Talán az egyetlen terület, amellyel kapcsolatban a Sex Offender program terapeutái rendszeresen szóba hozzák az egyébként elhallgatott kulturális kontextust, az a fiatal fiúk szexualitásának kérdésköre. A következőkben bemutatom, hogyan zajlott Mr. Rogers további kikérdezése, miután nem volt hajlandó elismerni, hogy szexuális fantáziái lettek volna a speciális program dolgozóival kapcsolatban.

„Nem is nagyon lett volna szükségem arra, hogy bárkivel eröszakos legyek - folytatta Rogers. - Amikor tizenhat évesen szabadultam, összejöttem a nagynéném egyik barátnőjével, egy huszonöt év körüli nővel. " A csoport erre hangosan felhorkant: „De hát ez egy újabb áldozattá válás!” Amikor Rogers értetlenkedve nézett körül, a mellette ülö, szintén afroamerikai Mr. Jenkins - a „programnyelv” afféle tolmácsaként - magyarázni kezdte számára, hogy tizenhat évesen volt egy huszonéves „barátnője”, aki prostituáltként is dolgozott neki. Jenkins közölte Rogersszel, hogy ő is itt, a Sex Offender programon ébredt rá, hogy áldozattá vált, egyebek mellett amiatt, mert később egyre inkább magáévá tette a „,bárkivel bármit megtehetek” attitüdöt, és most, harminchat évesen ö is áldozattá tett egy tizenéves lányt ${ }^{19}$.

Mr. Andrews ekkor közbeszólt, és elmesélte, hogy neki az édesanyja egyik barátnőjével volt szexuális kapcsolata tizenkét évesen. Idáig ő sem gondolt áldozatként önmagára, bár az események idején nagyon rosszulesett neki, amikor a nagybátyja egyszer azt vágta a fejéhez, hogy ő „megerőszakolta” a nőt.

\footnotetext{
19 A program természetesen nem teljesen így érti az áldozattá válásból fakadó „,pszichés károsodást”. Mr. Jenkins a huszonöt éves nővel való kapcsolata idején legfeljebb azt a hiedelmet alakíthatta ki, hogy „felnőttként tizenévesekkel szexuális kapcsolatot teremteni teljesen normális dolog” (a további élettörténetét pedig értelmezhetjük úgy, hogy ez az elképzelés vezetett később egy tizenöt éves lány áldozattá tételéhez, amiért börtönbe került). Az, hogy Mr. Jenkins azt a nézetet tette magáévá, hogy „,bárkivel bármit megtehet”, nyilvánvalóan nem a saját ,áldozattá válásából”, hanem abból fakadt, hogy prostituáltként dolgoztatta az illető nőt. A terapeuta nem javította ki: nyilvánvalóan az volt a fontos, hogy Jenkins képes volt áldozatként megnevezni önmagát.
} 
Mindettől függetlenül most sem igazán érzi áldozatnak magát. Amy ekkor megkérdezte, hogy van-e húga, majd amikor Andrews igennel felelt, a terapeuta az iránt érdeklődött, hogy mit érezne, ha a húga tizenkét éves lenne, és egy felnőtt férfi kezdeményezne vele szexuális kapcsolatot. Amikor Andrews azt felelte, nagyon dühös lenne, Amy így válaszolt: „,Akkor? Mi a különbség? Tehetünk-e bármiféle különbséget, ha fiú vagy ha lány az áldozat?"

A fiatal fiúk szexuális kapcsolatainak a Sex Offender programban történő átkeretezése több problémát is felvet:

- A program azt állítja, hogy kizárólag a kulturális kontextus - a fiúkkal szemben alkalmazott ítéletek különbségei - felelös azért, hogy felnőttként az „áldozatok” nem hajlandók elismerni, hogy korábban áldozattá váltak. Mivel a közösség azt sugallja, hogy a korai szexualitás a fiúk számára „dicsőség”, észre sem veszik, hogy kihasználták öket. A program tehát a nemek közötti egyenlőség elismerésének jegyében szeretné újrakonceptualizáltatni a résztvevőkkel a történeteiket (ahogy azt például Clancy szerint ${ }^{20}$ a gyermekkorban elszenvedett szexuális zaklatás áldozatai természetesen teszik).

- Mindezzel több gond is akad. Amíg a Clancy-féle kutatásokban részt vevő áldozatoknak gyerekként fogalmuk sem volt arról, hogy mit jelent az események ,szexuális jellege”, addig a program említett résztvevői valamenynyien tisztában voltak azzal, ami velük történt. Önmagukat az események ágenseiként élték meg, a tapasztalataikról pedig „örömteliként”, „pozitívként” számoltak be. Úgy tünt, a legtöbbjüknek nehézséget okoz, hogy azt állítsák: „traumatizálódtak” akkor, amikor ezek az események zajlottak. A zavart feltehetően az okozza, hogy a társadalom által a történtek értelmezésére kínált forgatókönyvek - amelyek az átélt érzelmeket is befolyásolják vagy meghatározzák ${ }^{21}$ - nem az ,áldozattá válás”, hanem a „férfiként való megszületés" szkriptjei. A program abban téved, hogy feltételezi, hogy a fiatal fiúk „traumát” éltek át, amit később a társadalmi elvárásoknak megfelelően módosítottak. Az önéletrajzokból ugyanakkor inkább az derül ki, a saját döntésen és beleegyezésen alapuló korai szexuális élmények épp a hozzáférhető forgatókönyvek miatt voltak már az átélésük pillanatában is örömteliek (vagyis nem utólag minősültek annak a közösség férfiakkal kapcsolatos nyomásának hatására).

- Az „áldozatszerep” elfogadására késztetett férfiak kapcsán az a probléma is felvetődik, hogy ez a pozíció némiképp elfedi az egyes konkrét esetekben

20 Susan A. Clancy: i. m.

21 Bodor Péter: Konstruktivizmus a pszichológiában. BUKSZ, 2002/1. 
vállalható egyéni felelősségüket. Ki zsákmányol ki kicsodát akkor, amikor a tizenhat éves Mr. Jenkins egy huszonöt éves prostituáltat „futtat”, és a nap végén az összes pénzét elveszi? Ki tesz áldozattá kit, amikor a tizenhét éves Mr. Robertson kapcsolatot kezd az iskolabusz huszonéves női sofőrjével, akit teherbe ejt, majd soha többé nem érdeklődik a megszületett gyerek iránt? Természetesen lehetne ezeket a helyzeteket jóval összetettebben is vizsgálni, sajnálatos módon azonban épp a program éles áldozat/elkövetö oppozíciója, illetve az ezekhez illesztett „pszichodinamikák” - mindig, minden körülmények között az elkövetöé a teljes felelősség - nem kedveznek azoknak az értelmezési kereteknek, amelyekben az ambivalenciát és a felelösség összetett jellegét lehetne elemezni.

- A program egyéb esetekben is használja az ,áldozat soha, semmilyen körülmények között nem vállalhat felelösséget, a legkisebb mértében sem" filozófiáját, még olyankor is, amikor a dolgozók maguk sincsenek teljesen meggyőződve annak érvényességéről. Emlékezzünk vissza például a „feltűnősködő” Mr. Spears történetére, akinek a magatartásáról a következőket mondta a terapeuta: ,Elfogadom, hogy nem szeretne flörtölni, és természetesen ha szexuálisan zaklatnák, az nem az ön hibája volna, mégis, gondolkozzon el azon, hogy idönként nem provokatív-e. Hogy nem veszélyes-e az ilyen viselkedés ebben a környezetben."

A Sex Offender program említett alapvetéseit röviden a következőképpen összegezném:

- Mivel a tizenévesekkel szexuális kapcsolatot teremtők a törvény szerint bünelkövetők, és a programban épp a deviáns szexuális érdeklödésüket kívánjuk bizonyítani, a nemek egyenlőségének elfogadása alapján egyértelmü, hogy áldozatokként kell tekintenünk azokra a tizenéves fiúkra is, akik korai szexuális tapasztalatokról számoltak be.

- Mivel alapelv az is, hogy az áldozatot hibáztatni kognitív torzítás, feltételezzük, hogy - életkortól és nemtől függetlenül - minden szexuálisbün-elkövető a szabad akarat és a felelősség birtokában lévő manipulátor, áldozatok pedig „traumatizáltak” és „manipuláltak”.

Az idézett példák remélhetőleg rávilágítottak arra is, hogy a program összegzett elvei sok esetben felülírják a szubjektív tapasztalatokat (mielött a fogvatartottaknak egyáltalán lehetőségük nyílna beszámolni azokról. Láthattuk például, hogy Mr. Rogersnek esélye sem volt arra, hogy a szabadulása után a 
nagynénje barátnőjével kialakított kapcsolatát jellemezze, hiszen azonnal elhelyezték az „áldozat” kategóriájában).

Természetesen adódik a kérdés, hogy mit kezd a program a továbbiakban az ily módon létrejövő áldozatokkal, vagy azokkal a fogvatartottakkal, akik a kezdetektől elismerték, hogy akár gyerekként, akár felnőttként áldozattá váltak.

A csoportfoglalkozásokon a résztvevőknek a másik személyére vagy büncselekményére tekintet nélkül, empatikusan kell végighallgatniuk a társaikat, vagy elfogadniuk a többiektől származó kritikát és tanácsokat. Mindez egyúttal azt is jelenti, hogy azok, akik gyermekkori szexuális abúzus áldozataivá váltak, kénytelenek kontrollvesztés és indulatkitörés, vagy egyéb negatív érzelmek kifejezése nélkül odafigyelni a hasonló büncselekmények miatt elítéltek részletes beszámolóira az önéletrajzok prezentációja vagy az esetleírások ismertetése során. „A program legnagyobb ellenmondása - fogalmazta meg egyszer James, a kezelés elveivel legkritikusabb terapeuta -, hogy különösebben nem törödünk azokkal a fogvatartottakkal, akik maguk is áldozatok. Nincs erre külön programpont vagy csoportfoglalkozás."

Az elítélt áldozatokkal való csekély mértékủ foglalkozás többnyire néhány egyszerü jó tanácsban vagy javaslatban merül ki a terapeuták részéről. Cindy például azt mondta a primary csoportja egyik tagjának, aki ötévesen vált szexuális erőszak áldozatává, hogy értse meg az ,áldozat” és a „túlélő” közötti különbséget. A „túlélő" nem hibáztatja magát többé a történtekért, elfogadja, hogy nem ő a felelös, és büntudat nélkül lép tovább. A „gyors továbblépés" lehetösége természetesen kizárólag azokkal a szexuálisbün-elkövetökkel kapcsolatban áll fenn, akik korábban áldozattá váltak. A Victim Empathy gyakorlat során senkitől sem hallottam, hogy az áldozat szerepét játszva azt állította volna, hogy könnyedén túltette magát a történteken. Valamennyi fogvatartott arról beszélt, hogy a büncselekmény óriási törést jelentett az életében, az után nagyon nehéz - ha nem lehetetlen - volt ismét talpra állnia.

Mindez egyúttal újabb példát kínál arra, hogy a Sex Offender program igyekszik fenntartani az áldozatok és a bűnelkövetők közötti éles, átjárhatatlan határvonalat. Annak érdekében, hogy a bünözőt a „manipulatív”, „,szándékosan ártani kívánó”, illetve ,,a szabad döntés birtokában lévő” és „,felelősségteljes” jelzőkkel lehessen illetni, vele szemben pedig a „manipulált” és „traumatizált” áldozat alakja váljon megalkothatóvá, óhatatlanul is arra van szükség, hogy a bünelkövetőket érő traumákat kisebbítsék. A szexuálisbünelkövető által elszenvedett korábbi abúzus így ,egy döntés következtében átléphető" eseménnyé alakul át, az arra való bármilyen hivatkozás a továbbiak- 
ban pedig kognitív torzításnak minősül, amellyel a bünöző csupán a saját felelősségét igyekszik csökkenteni.

A program során áldozattá alakított bünelkövetökkel - a korai szexuális tapasztalatokat szerzö férfiakkal - így voltaképp nem történik más, mint hogy szinte azonnal vissza is helyezik őket a bünözés kontextusába. A „traumáikat" nem kezelni szeretnék a terapeuták, hanem megtalálni azokban a későbbi büncselekmény gyökerét vagy forrását (ahogy Mr. Jenkins is „,felismerte" például, hogy a tizenhat éves kori viszonya során kialakított hiedelmei hogyan hozhatók kapcsolatba a jelenlegi cselekményével). Az összefüggés azonban egyirányú: a fiatalkori áldozattá válás a gondolkodási hibák létrejöttén keresztül vezethet ugyan büncselekményhez, de semmiképp sem használható a későbbiekben a felelősség elutasítására vagy csökkentésére. ,, A bünelkövetö elveszitette az arra való jogosultságát, hogy a továbbiakban áldozatként tekinthessen magára" - magyarázta nekem egyszer az Intenzív terápiás közösség egyik résztvevője, és ez a megközelítés alighanem a Sex Offender program esetében is helytálló.

\section{IRODALOM}

Andrews, Don A. - Bonta, James: The Psychology of Criminal Conduct. Anderson, Cincinnati, 2003

Auburn, Timothy - Lea, Susan: Doing Cognitive Distortions: A Discursive Psychology Analysis of Sex Offender Treatment Talk. British Journal of Social Psychology, vol. 42, 2003

Beggs, Sarah M.: Within-Treatment Outcome among Sexual Offenders: A Review. Aggression and Violent Behavior, vol. 15, 2010

Bodor Péter: Konstruktivizmus a pszichológiában. BUKSZ, 2002/1.

Buda Béla: Empátia. A beleélés lélektana. Folyamatok, alkalmazások, új szempontok. L'Harmattan Kiadó, Budapest, 2012

Center for Sex Offender Management: Understanding Sex Offenders: An Introductory Curriculum, 2004. http://www.csom.org/train/etiology/index.html

Center for Sex Offender Management: The Role of the Victim and Victim Advocate in Managing Sex Offenders. Corrections.com, July 272009.

http://www.corrections.com/news/article/21987

Clancy, Susan A.: The Trauma Myth. The Truth about the Sexual Abuse of Children - and Its Aftermath. Basic Books, New York, 2009

Douard, John - Schultz, Pamela D.: Monstrous Crimes and the Failure of Forensic Psychiatry. Springer, New York, 2012

Fernandez, Yolanda - Harris, Andrew J. R. - Hanson, R. Karl - Sparks, Jennifer: STABLE-2007 Coding Manual - Revised. 2012. http://www.jibc.ca/sites/default/files/course_outlines/SOAP106.pdf 
Foucault, Michel: Technologies of the Self. In: Martin, Luther H. - Gutman, Huck Hutton, Patrick H. (eds.): Technologies of the Self. Tavistock, London, 1988, pp. 16-49.

Foucault, Michel: Felügyelet és büntetés. Gondolat Kiadó, Budapest, 1990

Foucault, Michel: A szexualitás története. A tudás akarása. Atlantisz Kiadó, Budapest, 1996 Foucault, Michel: A pszichiátriai hatalom: a kikérdezés, a drog és a hipnózis. In: Rácz József Takács Ádám (szerk.): Drogpolitika, hatalomgyakorlás és társadalmi közeg. Elemzések foucault-i perspektívából. L'Harmattan Kiadó, Budapest, 2006

Lancaster, Roger N.: Sex Offenders: The Last Pariahs. The New York Times, 21 August 2011 Langan, Patrick A. - Schmitt, Erica L. - Durose, Matthew R.: Recidivism of Sex Offenders Released from Prison in 1994. U.S. Department of Justice, Office of Justice Programs, Washington, D.C., 2003

Marshall, William - Anderson, Dana - Fernandez, Yolanda: Cognitive Behavioral Treatment of Sexual Offenders. John Wiley and Sons, New York, 1999

Milkman, Harvey - Wanberg, Kenneth: Cognitive-Behavioral Treatment. A Review and Discussion for Corrections Professionals. U.S. Department of Justice. National Institute of Corrections, Washington, D.C., 2007

Rhodes, Lorna A.: Toward an Anthropology of Prisons. Annual Review of Anthropology, vol. 30,2001

Waldram, James B.: Challenges of Prison Ethnography. Anthropology News, vol. 1, 2009

Waldram, James B.: Hound Pound Narrative: Sexual Offender Habilitation and the Anthropology of Therapeutic Intervention. University of California Press, Berkeley, 2012 